\title{
AL-QURAN DALAM PERSPEKTIF BUDAYA
}

\author{
Oleh: Ajat Sudrajat \\ (Ilmu Sejarah - FISE - UNY)
}

\begin{abstract}
Abstrak
Al-Quran merupakan kitab suci terakhir yang diturunkan kepada manusia. Tujuan utama diturunkannya al-Quran adalah sebagai kitab petunjuk yang meliputi bidang akidah, syariah, dan akhlak. Akan tetapi di luar ketiga petunjuk tersebut, al-Quran telah memberikan motivasi dan inspirasi kepada umat Islam dalam berbagai bidang kehidupan sehingga melahirkan jenis budaya tertentu.

Dialog intelektual yang dilakukan secara kreatif oleh umat Islam terhadap al-Quran ternyata telah menghasilkan lahirnya generasi umat yang dipenuhi dinamika dan kreativitas. Sejarah telah membuktikan keunggulan budaya umat Islam pada masa klasik yang disebabkan dialog kreatif mereka terhadap al-Quran. Sebaliknya ketika al-Quran ditinggalkan, kelumpuhan dan kebekuan segera menyerang dan menjangkiti tubuh umat Islam. Oleh karena itu, sangat wajar ketika para pembaharu menyadari hal tersebut, mereka pun secara serentak menyeru umat Islam untuk kembali kepada alQuran.
\end{abstract}

\section{Pendahuluan}

Al-Quran adalah satu-satunya wahyu Allah yang masih ada hingga sekarang. Ia merupakan kitab suci yang tidak pernah tercampur dengan kebatilan dari mana pun dan tidak ada sesuatu pun yang diragukan dari padanya (QS. al-Baqarah (2): 2). Keadaan Al-Quran, sejak diturunkan pada lima belas abad yang silam sampai saat ini, tidak ada pengurangan atau penambahan sedikit pun terhadapnya. Semua ini merupakan jaminan dan penjagaan atasnya yang telah dijanjikan dan diberikan oleh Allah Swt. (QS. al-Hijr (15): 9).

Oleh karena itu, sebagai umat yang dipilih Allah untuk menerima kitab yang mulia ini, sudah seharusnya apabila umat Islam menjadikan al-Quran sebagai pedoman hidup dan mengaktualisasikan dirinya secara aktif dan kreatif. Umat Islam tidak semestinya memperlakukan al-Quran sebagai sungai yang kekeringan atau padang pasir yang tandus lagi gersang. Janganlah umat Islam berperilaku pasif 
seperti pengaduan Nabi Muhammad Saw. kepada Allah: "Ya Tuhanku, sesungguhnya kaumku menjadikan al-Quran ini sesuatu yang tidak diacuhkan" (QS. al-Furqan (25): 30).

Keluhan yang setara dengan pengaduan Nabi kepada Allah di atas, ternyata dikemukakan pula oleh seorang cendekiawan Muslim, yaitu Syaikh Muhammad al-Ghazali. Ia mengatakan bahwa dewasa ini banyak umat Islam yang mendengarkan al-Quran dengan tenang, tetapi tidak memberikan respons apa pun. Seolah-olah al-Quran diserukan dan dibicarakan kepada mereka dari tempat yang sangat jauh. Ia pun mengatakan bahwa sangat sulit sekarang ini untuk menemukan orang-orang yang benar-benar berpegang pada al-Quran (Muhammad al-Ghazali, 1996: 12).

Terdorong oleh keprihatinan Muhammad al-Ghazali di atas, tulisan ini akan mencoba untuk melihat kembali posisi Al-Quran dalam kehidupan umat Islam. Bagaimana kiranya apabila melihat posisi Al-Quran dari perspektif budaya. Melalui penglihatan yang demikian, uraian ini diharapkan dapat merangsang dan membangkitkan semangat untuk mengkaji al-Quran dan sekaligus melahirkan kreativitas dan dinamika dalam tubuh umat Islam.

\section{Al-Quran dalam Lintasan Sejarah}

Abdul Halim Mahmud, sebagaimana dikutip oleh Ahmad Syafii Maarif, mengatakan bahwa al-Quran yang dimiliki umat Islam sekarang ini adalah juga al-Quran yang dahulunya telah memersatukan suku-suku, menghimpun yang berserakan, memertemukan hati, menciptakan umat, mengokohkan sendi-sendi peradaban, dan telah membawa umat Islam mencapai puncak kemajuannya. Apa yang telah dikemukakan oleh sarjana Mesir tersebut bukanlah sesuatu yang ahistoris, ia merupakan kenyataan yang sepenuhnya historis, demikian lanjut Syafii Maarif (1990: viii).

Seperti diketahui, karena dorongan dan petunjuk al-Quranlah umat Islam pada masa klasik untuk beberapa abad menjadi umat yang kreatif, dinamik, terbuka, dan punya rasa percaya diri yang tinggi. Melalui modal tersebut, umat Islam tidak merasa canggung untuk bergumul dengan peradaban lainnya, seperti peradaban Yunani, Persi, India, dan kemudian Turki. Pergumulan kreatif ini kemudian berhasil membuahkan suatu identitas diri dan suatu peradaban yang khas Islam yang kosmopolitan. Para sarjana Muslim dan non-Muslim pun sampai pada kesimpulan bahwa mereka tidak dapat membayangkan munculnya gerakan renaisans di Eropa tanpa dorongan dan kontribusi 
umat Islam ketika itu. Secara tegas Milot mengatakan bahwa peradaban umat Islamlah yang telah memungkinkan terjadinya renaisans di Eropa. Peradaban Islam yang didasarkan pada al-Quran itulah yang telah menjadi mata rantai yang hilang, jembatan emas yang melintas di atas lubang hitam (black hole) sejarah Eropa (Milot, 2003: 30-31).

Sejak kira-kira permulaan abad ke-15, sekalipun di bidang politik dan militer umat Islam masih unggul, di bidang pemikiran dan intelektual, pada umumnya umat Islam mulai memasuki proses kejumudan dan kebekuan. Karya-karya kreatif yang bernilai tinggi tidak lagi bermunculan. Sejak periode tersebut umat Islam terbelenggu dengan tradisi taklid (ikut-ikutan) dan umat Islam terjebak dalam pengulangan-pengulangan karya-karya terdahulu. Karya-karya yang lahir terbatas pada bentuk komentar atau ulasan, tanpa mempunyai kemampuan untuk menampilkan orisinalitas pemikiran, apakah itu dalam bidang hukum, filsafat, ilmu dan tekonologi, atau pun dalam bidang sosial kemanusiaan. Dalam penilaian Syafii Maarif, dunia Islam seakan-akan kikir untuk melahirkan bibit-bibit unggul dari dalam rahimnya. Kebekuan ini melanda dunia Islam sekitar lima abad yang diakhiri dengan kebangunan kembali umat Islam sekitar abad ke20 (Syafii Maarif, 1990: ix). Kalau sebelumnya peradaban umat Islam menjadi jembatan emas yang melintas di atas kebekuan peradaban Eropa, kini sebaliknya umat Islam mengalami nasib yang berbeda.

Apabila para pembaharu di dunia Islam, dalam rangka kebangunannya kembali dan upaya untuk melepaskan diri dari cengkeraman kolonialisme Barat, menyerukan kembali kepada alQuran, berarti bahwa umat Islam harus menempatkan kembali posisi al-Quran pada posisi yang sentral. Umat Islam harus membaca kembali al-Quran secara benar. Membaca tidak hanya dalam pengertian tartil, melainkan membaca yang diikuti dengan pemahaman dan analisis yang kritis. Membaca al-Quran berarti memelajari, memahami, menganlisis, dan mengungkap semua pesan dan kandungan yang terdapat di dalamnya.

Apabila al-Quran hanya sekedar menjadi bacaan keagamaan dan diperlakukan sebagai mantera, maka sudah pasti al-Quran akan kehilangan relevansinya terhadap realitas-realitas dalam kehidupan alam semesta. Al-Quran berisi banyak hal yang berkaitan dengan dasar-dasar pemikiran. Sebagimana diketahui bahwa semangat yang terdapat dalam al-Quran adalah kegiatan pemikiran. Selain itu, alQuran juga memuat banyak hal yang bersifat dialogis terhadap alam semesta. Dari banyak hal yang menyangkut realitas alam semesta 
dapat diketahui keagungan Allah sebagai Penciapta alam ini. Kenyataan yang terjadi sekarang adalah bahwa yang mengkaji dan memikirkan segala sesuatu yang merupakan ciptaan Allah adalah orang-orang atau bangsa-bangsa di luar Islam. Padahal umat Islamlah yang seharusnya memiliki semangat yang demikian, karena memiliki dasar yang kuat dari kitab suci yang menjadi miliknya, yaitu AlQuran.

Sebagimana telah disebutkan di atas, al-Quran telah membuktikan dirinya mampu membentuk jiwa, membangun bangsa dengan peradaban yang tinggi. Oleh karena itu, sudah saatnya umat Islam mengkaji al-Quran tanpa harus menyampingkan pentingnya membaca al-Quran dalam pengertian tartil. Al-Quran harus kembali didialogkan dengan akal pikiran sehingga melahirkan umat Islam dan kaum Muslimin yang dinamis, kreatif, dan berbuat banyak untuk kemaslahatan alam semesta. Ini harus dilakukan, karena seperti yang disinyalair oleh Syafii Maarif, penalaran humanistik yang terlampau jauh dalam peradaban Barat, sedikit demi sedikit telah membabat orientasi sipritual-transendetal. Salah satu akibatnya adalah semakin berkembangnya budaya materialistik yang mencabut akar spiritual dari kehidupan manusia. Dengan kembali kepada orientasi yang diarahkan oleh al-Quran, peradaban manusia akan terhindar dari keterjerumusannya pada peradaban serba benda dan memberikan keseimbangan antara yang material dan spiritual (Syafii Maarif, 1990: ix).

\section{Al-Quran dalam Perspektif Budaya}

Apabila yang dimaksudkan dengan budaya atau kebudayaan adalah totalitas kegiatan intelektual yang dilakukan oleh individu atau masyarakat dengan semua implikasinya (Musa Asy'ari, 1988: 24), maka al-Quran merupakan sumber kebudayaan yang sangat kaya. AlQuran, seperti telah dibuktikan dalam lintasan sejarah umat Islam, berperan sebagai poros atau sumber utama kehidupan kaum Muslimin. Al-Quran dalam kehidupan umat Islam telah berfungsi sebagai sumber petunjuk, sumber inspirasi, dan sumber semangat.

Ketika umat Islam, baik secara perseorangan maupun kelompok, melakukan dialog intelektual dengan al-Quran, maka akan dihasilkan buah yang sangat lezat dan nikmat untuk dirasakan. Umat Islam akan merasakan dan sekaligus menikmati manfaat yang luar biasa dari petunjuk-petunjuk yang terdapat di dalamnya. Menurut Quraish Shihab, apabila seseorang mencoba untuk memelajari sejarah al- 
Quran, maka tujuan yang utama dari diturunkannya al-Quran adalah sebagai kitab petunjuk, seraya mengutip ayat 185 dari surat alBaqarah yang artinya: "Al-Quran sebagai petunjuk bagi manusia dan penjelasan-penjelasan mengenai petunjuk itu, dan pembeda antara yang hak dan yang bathil" (QS al-Baqarah (2): 185) (Quraish Shihab, 1994: 41).

Dari sisi al-Quran sebagai kitab yang memberikan petunjuk kepada manusia sehingga dapat menjalankan kehidupan sesuai dengan tujuan penciptaan, terlihat dari tiga petunjuk utamanya. Pertama, alQuran memuat akidah dan kepercayaan yang tersimpul dalam keimanan akan keesaan Allah dan kepastian akan datangnya hari pembalasan. Kedua, aal-Quran memuat syariah dan hukum-hukum dengan jalan menerangkan dasar-dasar hukum yang harus diikuti oleh manusia dalam hubungannya dengan Allah dan sesamanya. Ketiga, alQuran memuat petunjuk mengenai akhlak dengan jalan menerangkan norma-norma keagamaan dan susila yang harus diikuti oleh manusia dalam kehidupannya secara individual atau kolektif. Dalam ungkapan yang lebih singkat, al-Quran adalah petunjuk bagi seluruh manusia ke jalan yang harus ditempuh demi kebahagiaan hidup di dunia dan di akhirat kelak (Quraish Shihab, 1994: 40).

Apabila umat Islam secara aktif melakukan dialog intelektual dengan al-Quran atas tiga petunjuk tersebut dan mempertemukannya dengan petunjuk-petunjuk operasional yang dilakukan oleh Nabi Muihammad Saw., sungguh akan lahir corak kesadaran keagamaan yang tinggi. Dalam praktiknya, umat Islam akan mengalami transformasi spiritual secara penuh yang tidak kering dan parsial. Perilaku umat Islam betul-betul akan mencerminkan perpaduan yang indah antara keberimanan dan amal yang shalih.

Pada saat yang bersamaan, ketika dialog itu terus berlanjut, maka sejumlah cabang keilmuan yang bercorak keagamaan pun akan lahir. Berapa banyak cabang keilmuan yang telah lahir sebagai akibat dialog intelektual yang berkaitan dengan masalah ketuhanan; demikian juga dengan keilmuan yang lahir akibat dialog intelektual dengan masalah syariah dan akhlak. Berbagai cabang keilmuan yang bercaorak keagamaan ketika umat Islam melakukan dialog intelektual dengan al-Quran secara representatif dapat dilihat dari sejumlah mata pelajaran atau mata kuliah yang terdapat dalam kurikulum pendidikan sejak dari TK sampai Perguruan Tinggi.

Dengan demikian, dialog intelektual umat Islam dengan alQuran sebagai kitab petunjuk - akidah, syariah, dan akhlak - tidak saja telah melahirkan perilaku atau budaya tertentu yang didasarkan pada 
al-Quran, tetapi juga produk-produk lain dalam bentuk lahirnya berbagai cabang keilmuan keagamaan. Oleh karena itu, al-Quran telah memberikan sumbangan yang besar dan kaya terhadap khazanah kebudayaan manusia, khususnya umat Islam, dan masyarakat dunia pada umumnya.

Selain al-Quran berperan sebagai kitab petunjuk, al-Quran juga memuat ajakan kepada umat Islam dan manusia pada umumnya untuk membaca alam dan merenungkan segala rahasia yang terdapat dalam ciptaan Allah. Salah satu faktor penting yang terdapat dalam al-Quran adalah selain ayat-ayatnya berbicara tentang kehidupan makhluk Allah, al-Quran juga mengarahkan agar manusia melakukan dialog intelektual dengan seluruh ciptaan Allah tersebut. Jika demikian, apakah hubungan al-Quran dengan ilmu pengetahuan?.

Membahas hubungan antara al-Quran dan ilmu pengetahuan bukanlah dengan cara, misalnya dengan mengatakan adakah teori politik, teori ekonomi, dan teori-teori lainnya dalam al-Quran; tetapi yang lebih utama menurut Quraish Shihab adalah dengan melihat adakah jiwa ayat-ayat yang terdapat dalam al-Quran menghalangi perkembangan ilmu pengetahuan atau sebaliknya, serta adakah ayatayat di dalam Al-Quran yang bertentangan dengan hasil penemuan ilmiah yang telah mapan? Oleh karena itu, posisi al-Quran di sini adalah sebagai sumber motivasi dan inspirasi bagi lahir dan berkembangnya ilmu pengetahuan bukan merupakan sumber segala ilmu (Quraish Shihab, 1984: 41).

Selama ini memang ada kesan yang tertangkap dari sebagian umat Islam yang menyatakan bahwa al-Quran adalah merupakan sumber segala ilmu pengetahuan. Menurut Achmad Baiquni, ada kesalahfahaman dalam anggapan tersebut, meskipun tidak seorang pun dapat menyangkal bahwa di dalam al-Quran telah diletakkan dasar-dasar peraturan hidup manusia dalam hubungannya dengan Allah dan interasksinya dengan sesama manusia dan dalam tindakannya terhadap alam sekitarnya. Namun demikian, al-Quran bukanlah buku pelajaran kosmologi, biologi, atau sains pada umumnya. Al-Quran menurutnya harus dibaca sebagaimana seorang detektif membaca dan meneliti terjadinya suatu peristiwa. Dengan membaca garis-garis besar yang terdapat dalam al-Quran, umat Islam dituntun untuk membaca seluruh ciptaan-Nya secara rinci, dengan mengutip ayat 101 surat Yunus, yang artinya: "Katakanlah (wahai Muhammad): Periksalah dengan menggunakan nazhar segala apa yang terdapat di langit dan di bumi” (Achmad Baiquni, 1994: 1). 
Ketika umat Islam atau manusia pada umumnya mencermati perintah itu dan kemudian melakukan dan melaksanakannya, niscaya hasil dari nazhar itu adalah seluruh jenis cabang ilmu pengetahuan yang telah dan akan dikembangkan oleh umat manusia. Pada saat manusia membaca dan mencermati kehidupan ciptaan Allah yang ada di angkasa, kira-kira berapa banyak cabang ilmu pengetahuan yang lahir dari padanya? Pada saat manusia membaca dan mencermati ciptaan Allah di daratan, berapa banyak cabang ilmu pengetahuan yang lahir dari padanya? Sesaat manusia membaca dan mencermati dirinya sendiri dan interaksinya dengan orang lain dalam segala aktivitasnya, seperti dalam kegiatan politik, sosial, ekonomi, dan lainnya, berapa banyak cabang ilmu pengetahuan yang lahir daripadanya? Dalam surat al-Qamar (54) ayat 49 Allah mengatakan, yang artinya: "Sesungguhnya Kami menciptakan segala sesuatu menurut ukuran" (QS. al-Qamar (54): 49).

Sebagai akibat dari respons umat Islam dan manusia pada umumnya terhadap apa pun yang merupakan ciptaan Allah (al-Khaliq) baik di langit maupun bumi ternyata telah lahir kebudayaan dan peradaban yang sangat kaya dan beraneka ragam. Dalam posisi ini alQuran merupakan sumber inspirasi yang telah memotivasi kreativitas dan dinamika umat manusia dalam ruang lingkup yang tidak terbatas. Posisi al-Quran yang demikian diakui kebenarannya oleh Bucaille ketika mengatakan bahwa untuk pertama kalinya dalam sejarah kerohanian umat manusia, ada Kitab Suci (baca al-Quran) yang menyuruh umat manusia agar merenungkan gejala-gejala yang dapat ditangkap oleh pengamatan manusia untuk mengkajinya dengan tujuan menemukan ayat-ayat (tanda-tanda) kebenaran dan keberadaan Allah Swt. (Maurice Bucaille, 1994).

Bucaille lebih jauh mengatakan bahwa dalam al-Quran ditemukan jenis ajaran yang sama sekali baru agar manusia memperbaiki pengetahuan sekulernya. Banyak orang yang mengakui bahwa sains mengalami perkembangan yang luar biasa setelah mendapat dorongan dari al-Quran. Banyak ayat dalam al-Quran yang memuat data yang bisa diamati oleh orang-orang yang dikarunia Allah akal pikiran yang cemerlang (ulil albab). Al-Quran juga menekankan perlunya manusia memiliiki pengetahuan, sehingga implikasinya adalah menemukan dan mengembangkan sains (Maurice Bucaille, 1994).

Bagi umat Islam yang berkiblat pada al-Quran, tidak sewajarnya kalau mereka membelakangi alam semesta beserta isinya yang menyimpan berbagai rahasia; akan tetapi mereka harus berusaha untuk 
mengungkapkannya sebagai pelaksanaan tugas dalam rangka memakmurkan bumi dan menjadi saksi atas manusia. Ayat-ayat kauniyah merupakan suatu petunjuk dan mengkajinya merupakan perintah agama, sekaligus sebagai jalan untuk menuju keimanan yang benar. Allahlah yang telah menempatkan manusia di tengah alam semesta, yang di dalamnya dimensi ruang dan waktu diberlakukan.

Al-Quran, sekali lagi, merupakan i'jaz 'ilmi karena telah menempatkan manusia di tengah etos ilmu dan membuka pintupintunya untuk mengkaji ilmu pengetahuan. Namun demikian, seperti telah disebutkan di muka, al-Quran bukanlah kitab sains yang memuat berbagai teori ilmiah. Oleh karena itu, menurut Muhammad al-Ghazali penting untuk menegaskan bahwa kaidah ilmu dan perangkat pemahamannya adalah produk manusia dan usaha manusia yang diliputi relativitas atau kenisbian, sedangkan wahyu Allah (al-Quran) tidak seorang pun yang berhak mereduksinya (Muhammad al-Ghazali, 1996: 267).

Ketika dialog intelektual terus dilakukan terhadap al-Quran dalam bentuk respons umat Islam terhadap ciptaan Allah dan sepanjang hal itu tetap berada dalam payung al-Quran, maka ilmu yang lahir dari padanya bersifat Qurani. Dengan demikian semua implikasi yang bersifat mengiringi ilmu-ilmu tersebut dengan sendirinya juga bersifat Qurani. Dalam perkataan yang lain, dialog intelektual umat Islam terhadap al-Quran dengan sendirinya akan melahirkan produk budaya, baik berupa pemikiran, aturan-aturan, hukum-hukum, perilaku individu dan kolektif, serta produk-produk material lainnya, yang bersifat Qurani dan sekaligus Islami. Dalam hal ini Islamisasi ilmu pengetahuan dan yang mengiringinya secara otomatis terjadi secara simultan.

Demikianlah al-Quran memerintahkan kepada manusia untuk terus berupaya meningkatkan kemampuan ilmiahnya. Manusia dimotivasi oleh al-Quran untuk terus mengembangkan sains dan teknologinya dengan memanfaatkan anugerah Allah yang dilimpahkan kepadanya. Namun demikian, pada saat yang bersamaan, manusia selalu diingatkan dan juga diarahkan untuk tidak memperturutkan nafsunya. Karena apabila yang terjadi seperti itu, maka bukan hanya bahaya yang akan mengancam dan menimpa kehidupan manusia, tetapi bahkan adalah kehancurannya

Sebagai kitab suci yang bertujuan untuk memberikan petunjuk kepada umat manusia di mana pun dan kapan pun, dapat dipastikan bahwa al-Quran senatiasa akan berhadapan dan berdialog dengan beraneka macam budaya. Dari sudut pandang ini, ketika budaya 
dimaknakan sebagai suatu model pendekatan terhadap al-Quran, maka al-Quran bisa berfungsi melegitimasi, meluruskan, dan menolak sama sekali budaya tersebut. Sudah lumrah diketahui bahwa posisi al-Quran terhadap kebudayaan Arab misalnya, adalah berkisar pada tiga fungsi di atas. Al-Quran misalnya melegitimasi tradisi musyawarah yang biasa dilakukan oleh pemerintahan konfederasi suk-suku Quraisy sebelum kedatangan Islam. Al-Quran misalnya meluruskan posisi anak perempuan di atas anak laki-laki mereka. Al-Quran juga menolak untuk menerima cara-cara jahiliyah yang melakukan praktik riba (Hasan Ibahim Hasan, 2002: 112-134).

Tanpa bermaksud mengingkari tiga fungsi di atas, ketika alQuran berhadapan dengan suatu budaya, akan terjadi dialog yang kreatif di antara keduanya. Berkembangnya model penafsiran terhadap al-Quran sejak masa klasik Islam sampai dengan masa modern dapat dijadikan bukti telah terjadinya dialog yang kreatif antara al-Quran dengan perkembangan budaya manusia. Berkembangnya modelmodel tafsir al-Quran seperti tafsir bi al-Ma'tsur, bi al-Ra'yi (Penalaran), Shufy (Tasawuf), Fiqhy (Fiqh), Falsafy (Filsafat), 'Ilmy (Ilmiah atau Ilmu Pengetahuan), dan Abady (Kemasyarakatan) ('Ali Hasan al-'Aridl, 1992: 40-72), menguatkan adanya kontekstualitas alQuran terhadap kecenderungan budaya manusia.

\section{Kesimpulan}

Dari uraian di atas dapat diberikan beberapa kesimpulan sebagai berikut:

1. Al-Quran merupakan kitab suci yang tujuan utamanya adalah menjadi petunjuk kehidupan bagi manusia. Dengan mengikuti petunjuk dalam al-Quran, manusia akan bergerak ke jalan yang searah dengan tujuan penciptaannya.

2. Al-Quran telah membuktikan dirinya sebagai kitab petunjuk yang berhasil membentuk kehidupan sosial yang memiliki keseimbangan material dan spiritual. Syarat yang harus ditempuhnya adalah dilakukannya dialog yang kreatif dan terus menerus, sehingga al-Quran menjadi jiwa dalam kehidupan.

3. Dialog intelektual yang dilakukan secara kreatif dan terus menerus terhadap al-Quran pada saatnya akan melahirkan jenis kebudayaan tertentu yang bersifat Qurani. Kebudayaan yang lahir, baik dalam bentuk pemikiran, aturan-aturan, tatanan sosial, maupun yang bercorak material, tidak akan lepas dari jiwa al-Quran. 
4. Apabila al-Quran dihadapkan dengan suatu jenis kebudayaan tertentu, setidaknya ada tiga fungsi yang melekat padanya, yaitu memberikan legitimasi, meluruskan (memperbaiki), dan menolak sama sekali. Meskipun demikian, sangat mungkin akan terjadi dialog yang kreatif antara al-Quran dengan kebudayaan tersebut. Lahirnya beraneka tafsir terhadap al-Quran merupakan salah satu bukti dari adanya dialog kreatif tersebut.

\section{Daftar Pustaka}

Depag RI. (1995). Al-Quran dan Terjemahnya, Jakarta: Depag RI.

Al-‘Aridl, 'Ali Hasan. (1992). Sejarah dan Metodologi Tafsir. Jakarta: Rajawali Press.

Asy'arie, Musa, dkk. (eds.). (1988). Agama, Kebudayaan dan Pembangunan. Yogyakarta: IAIN Sunan Kalijaga Press.

Baiquni, Achmad. (1994). Al-Qur'an: Ilmu Pengetahuan dan Teknolog., Yogyakarta: Dana Bakti Wakaf.

Bucaille, Maurice. (1994). "Reflections on Religion and Science in Connection with the Scientific Anticipations of the Qura'an". Makalah disampaikan dalam International Seminar on Miracle of al-Qur'an and al-Sunnah on Science and Technology, pada tanggal 29 Agustus - 1 September 1994 di Bandung.

Fedespiel, Howard M. (1996). Kajian al-Quran di Indonesia. Bandung: Mizan.

Al-Ghazali, Syaikh Muhammad.(1996). Berdialog dengan Al-Quran. Terj. Masykur Hakim dan Ubaidillah. Jakarta: Mizan.

Hasan, Hasan Ibrahim, Sejarah Kebudayaan Islam, Jilid 1, Jakarta: Kalam Mulia, 2002.

Maarif, Ahmad Syafii. (1990). “Al-Qur'an dan Tantangan Modernitas: Sebuah Pengantar", dalam Ahmad Syafii Maarif dan Said Tuhuleley (ed.). Al-Qur'an dan Tantangan Modernitas, Yogyakarta: SIPRESS. 
Milot, Jean-Rene. (2003). Meretas Akar-Akar Permusuhan Islam Kristen. Terj. Kanis Dursin. Jakarta: OBOR.

Shihab, M. Quraish. (1994). Membumikan Al-Quran. Bandung: Mizan.

(1996). Wawasan al-Quran: Tafsir Maudhu'i atas Pelbagai Persoalan Umat. Bandung: Mizan.

\section{Biodata Penulis}

Dr. Ajat Sudrajat, M.Ag, dilahirkan di Ciamis, 21 Maret 1962, menamatkan studi S3 dari UIN Sunan Kalijaga Yogyakarta Jurusan Pengkajian Islam (2009), dan adalah dosen tetap pada Jurusan Pendidikan Sejarah Fakultas Ilmu Sosial dan Ekonomi dan UPT MKU untuk mata kuliah Pendidikan Agama Islam Universitas Negeri Yogyakarta. 
